\title{
A PRAGMATIC STUDY OF SPEECH ACT OF ADVICE IN SELECTED ENGLISH AND ARABIC CHILDREN'S STORIES
}

\author{
AYA HUSSEIN ABASS, PROF. ABDUL KAREEM FADHEL JAMEEL \\ University of Baghdad/College of Education \\ Ibn Rushd for Human Sciences/ English Department
}

DOI: $10.37648 / \mathrm{ijrssh.v10i03.025}$

Received: 19 $9^{\text {th }}$ June, 2020; Accepted: 08th July, 2020; Published: 29th July,2020

\begin{abstract}
This research paper examines the forms and contents of three types of advice speech acts in some selected children's bedtime stories. Directives are functions to direct the behavior of people. Advice is regarded as a directive speech act. It is used to influence people to do something. The hearer is directed by the speaker and he has the decision either to take this opinion or not. According to many writers, there are three types of advice direct, indirect and conventionally indirect. However, the aim of this study is to survey and compare the strategies of advice in English and Arabic bedtime stories. The problem is which devices are frequently used by parents that influence the children's thinking. There are three types of advice: direct, indirect and conventionally indirect. The traditionally use of these types of advice in random Arabic and English bedtime stories.

It is hypothesized that the types of advice can be existed in different texts even in the children's bedtime stories. Advice is a directive speech act which is applicable as a linguistic phenomenon in children's English and Arabic short stories.

Discussing the selected data would be done to demonstrate how advice is delivered and to what degree its intended meaning was effectively communicated to demonstrate the realistic value; and with respect to the syntactic devices of any selected form. The analysis is hoped to be abstract in nature. Theoretically, it would lead to theoretical pragmatism, as it will shed light on the basic rules regulating the development of speech acts. This thesis is also hoped to lead to studies in different aspects of language.
\end{abstract}

\section{INTRODUCTION}

According to Huang (2006, p:291), speech act as "Speech acts theory is that the uttering of a sentence is, or is of an action within the framework of social institutions and conventions. Put in slogan form, saying is (part of) doing, or words are (part of) deeds." Speech acts theory refers to do more than one thing at the same time and expresses the speaker's intention. This theory is used to explain language not only for saying something, but for doing things, for instance, when someone says 'I am sorry' means the act of apologize occurs.

The theory of speech acts is traced back to the British linguist philosopher (John Longshan Austin) who works to develop the performative utterances and formulates the theory of speech acts. His findings are given at Harvard University in 1955 as the lectures of William James that are published in his popular book "How to Do Things with Words" after his death. 
J.L. Jr. Austin points to the three forms of speech acts: Locutionary act (the act of speaking and expressing something using other expressions), Illocutionary act (the act is done through the use of language (satingalert- wishing ... etc.), and Perlocutionary (the effect of the illocutionary act on the listener (persuading shocking - convincing) or the act of speaking / writing).

In contrast, Searle (1968, p:405) opposes the division of Austin, and instead suggests his own. He reformulates the definition of the illocutionary act, and proposes another word, the so-called propositional act that expresses the proposition (a neutral phrase without illocutionary force).

Depending on Searle, Levinson(1983; 240) refers to the five major categories of illocutionary acts: representatives, directives, commissives, Expressives, Declarations.

\section{HISTORICAL OVERVIEW}

Generally speaking, pragmatics according to (Yule, 1996:4), refers to the meaning of contextual expressions and to the relationship between the form (structure) and the speaker using that form. Morris (1938: 6) also defines pragmatics as "the study of how sings and interpreters are related to each other".

Finch (2000: 150), "Pragmatics focuses on what is not explicitly specified and how we perceive utterances in the sense of circumstances. They are concerned not so much with the sense of what is being said as with its force, that is, with what is being communicated by an utterance's way and style.'

\section{SPEECH ACT THEORY}

Theory of speech act is introduced as "theory of thinking" by J.L. In the course of time, Austin is updated and adapted to be regarded as "speech act theory" and later embraced and further expanded by the American philosopher Searle (1969) in his influential book entitled Speech Act.

Sadock (2007: 54) declares that Austin gives his lectures on the theory of speech acts, these lectures are given in Harvard in 1955. His lectures are then published in 1962 as a book under the name "How to Do Things with Words."
Austin begins speech act theory by the distinction between "statements" and what he refers to call "constative" and another type of utterances which he calls performatives, the former is "the descriptive sentences that until Austin were the principle concern of philosophers of language sentences that seen... to be employed mainly something". This means that philosophers consider only the truth and the falsity of sentences as in:

\section{1) It is cold outside}

Huang (2007, p:94) supports this idea that constatives are used to make "statements or assertion". From this example the speaker can examine the truth and falsity by going outside and check the weather. In contrast, the latter "performatives" refer to the utterances that are used to do something not only saying it. They meet a set of "happiness" or "felicity" conditions (Mey, 2001, p: 23) such as:

\section{2) Have a nice time}

In this example, Austin (1962, p:12) argues that the speakerintends to express his wish by using such words or expressions, or as he puts it "to say something is to do something". Moreover, he adds that we often do things with words when we use them to perform actions such as promising, welcoming, boasting, affirming, advising, and so on.

Levinson (1983, p:231) mentions that there are two internal shifts in "Austin's arguments". Firsty, the shift from the idea that there are general class of performatives including explicit and implicit performatives. In other word, Huang (2007, p:94) the act can be performed by some verbs in which speakers inform the listener to do the action not just saying it for example:

\section{3) "I do" as uttering the course of the marriage ceremony}

Secondly, the shift is from performatives/ constatives to speech act theory.Austin gives no attention to performatives and constatives because they are dominated by "felicity conditions" and they are not used to differentiate the truth conditional terms (Huang, $\mathrm{p}: 100)$.

According to Haiman (1993 p:16) speech act theory is reasonable to use when the utterances contain threats or physical or mental harm. This type is called situationaltering speech acts because they leave their victims with no choice of what to do to be coercive not 
persuasive. From the previous speech one can conclude that speech act aims to show how actions can be achieved by words, phrases, and sentences. The facts of speech act theory have been on utterances especially those in conversational and face- to- face situations.

There are two flaws of speech act theory which are theoretical and empirical in order to inform the addressee how to do things in a conversation. The first one is that There are some characteristics of actions like offering, requesting, in which the actions are performed (in saying something). The second one is that individual utterances have force a speaker performs not only a literal act "an assertion, question, or directive), but also a primary act " a request, offer, promise and threat. These acts are called speech act (Sadock,1974, p: 471).

\subsection{Austin (1962)}

J.L. Austin is the first philosopher who highlighted the concept of speech act theory and the use of utterances not only to say something but also to perform the action which are called performatives. He (1962, p: 6) refutes the traditional philosophical view which concerns with how to describe statements either this state of affairs or to state some facts that can be either true or false these statements are called constatives.Levinson (1983, p: 134) argues that Austin during his investigations, the distinction between constative and performative should be abandoned. He (ibid) notices that the declarative sentence can be described as a part of action not as a state of affairs. Although the sentence I state that there is life on earth has been already deemed as an example of the constatives, it shows a strong tendency towards the performatives. Similarly, the verbs: assert, declare, claim, mention, etc., seem to bear all the hallmarks of a performative verb. Quirk et al. (1985: 804) supports this view that there is no clear distinction between performatives and constatives (statements).

\subsection{Searle (1969)}

In 1969, the American philosopher John Searle, published his Speech Acts as an analytical modification and systematization of Austin's theory in connection with a single speech act. He attempted to postulate the necessary and sufficient conditions for the performance of the speech act of "promise" in the hope that this would be taken as a practical step in the way that setting a pattern for analyzing other kinds of speech acts in general, to be followed by extracting the corresponding semantic and syntactic rules which mark the utterance as an illocutionary act of a certain type (Searle, 1971, p: 40).

Searle (ibid, p:17) argues that speaking language is engaged by behavior. This means when someone asks question, makes statements, gives commands, ...etc., these acts are performed according to the rules of language. He ( ibid, 16) clarifies that speech acts are the basic units of linguistic communication, as the production of an utterance under certain conditions constitutes issuing a speech act.

\subsection{Locution, Illocution and Perlocution}

Abandoning the dichotomy of constative / performative, Austin (1962: 101ff) explains that in issuing an utterance, a speaker can perform three acts simultaneously, namely: locutionary, illocutionary and perlocutionary acts According to Leech (1983: 200) these acts are :

1- a locutionary act is the main act of speaking which consists of three sub acts, (a) phonic "act of producing an utterance inscription" or (the act of vocal noises). (b) phatic "an act of composing particular linguistics expression in particular language" or (the act of words conforming to the lexicogrammtical rules). (c) rhetic "an act of contextualizing the utterance- inscription" or (the act of using these words with certain sense and reference), (Huang, 2007: 102).

2- Illocutionary act, when someone says something with a specific purpose with reference to the communicative intention of the speaker's mind. By uttering certain words, a speaker can state, request, apologize, promise, approve, welcome, etc. By saying, for example, Get out, the speaker is performing the act of ordering someone to get out. Austin (1962: 28) expresses his interest in these actions and even the term " speech act" is taken to mean an illocutionary act.

3- Finally, perlocutionary acts refer to the effect of utterance on the addressee. It can be defined as "the act by which the illocution produces a certain effect on the addressee". This means that the consequential effects of uttering something on the audience or listener, such effects being unique to the relevant circumstances. (Huang, 2008: 103).

\subsection{Direct and indirect speech acts}

Yule (1996: 54) states that there are three types of speech acts according to the three basic types of sentences. There is a relation between the three 
(IJRSSH) 2020, Vol. No. 10, Issue No. III, Jul-Sep

functions forms (declarative, interrogative, imperative) and three functions ( statement, question, command/ request), such as

- You wear a seat belt. (declarative)

- Do you wear a seat belt? (interrogative)

- Wear a seat bel! (imperative)

Huang (2007, p: 110) highlights that there is a direct speech act if there is a match between a sentence type and illocutionary force. In another word if there is a relationship between the structure and the function, for example:

\section{4) Move out of the way}

Whereas if there is no relation between sentence types and illocutionary force, this is called indirect speech act as in:

\section{5) Could you pass me the salt?}

In this example, the sentence is question in structure but the function is used as a request.According to crystal (2008, p: 232) that the indirect speech act refers to "an utterance whose linguistic form does not directly reflect its communicative purpose" as in "I'm feeling cold" functions as a request for someone to close a door. He (ibid) also adds when the speaker says "I have a cold" is a direct speech act.

\subsection{Taxonomies of Illocutionary Acts}

Austin verifies his five general classes of illocutionary acts. He says "I am not putting any of this forward as in very least definitive...I have not succeeded in making clear even to myself. It could well be said that all aspects are present in all my classes", (Austin, 1962, p: 151). There are five classifications (taxonomies) of illocutionary acts:

1. Verdictives: Bach\&Harnish (1979: 115; Bach, 1999: 152) provide that verdictives are classified by giving of a verdict and consist in the delivering of finding, official or unofficial and concern with institutional facts rather than natural facts.

2. Exercitives : it is the category which focus of decisions in favour of or against a certain course of action. The verbs of exercitives are beg, order, command, entreat, and advise. Request is also an example of exercitive but Austin does not list it, (Searle, 1979: 8).

3. Commissives: are characterized by undertaking or promising. According to Austin commissives are one category of illocutionary

\section{e-ISSN: 2249-4642, p-ISSN: 2454-4671}

acts and the main point in this category is to commit the speaker in a specific kind of action (Austin, 1962: 151; Bach\& Harnish, 1999: 151).

4. Expositives: these acts are used in exposition and explain how the speakers' utterances fit to the conversation, Austin lists examples of expostives such as : affirm, deny, illustrate, report, object to, and call.

5. Behabitives: one class of illocutionary acts which includes "the notion of reaction to other people's behavior, fortunes, attitudes and expressions of attitudes to someone else's past conduct or imminent conduct". Austin lists the acts as: apologize, deplore, thank, welcome and felicitate.

It is obvious that from Austin's lists these are not illocutionary acts but are illocutionary verbs. Searle (1979: 1) takes into account the classification of these acts by Austin which are verdictives, expostives, exercitives, commisives, and behabitives. He (ibid) redevelops Austin's classifications for the reason to make a distinction between illocutionary acts and illocutionary verbs. Searle (1979, p:12) classifies five types of illocutionary:

1. Assertives : are types of speech act in which the speaker is committed to the truth of expressed proposition or to something being in case. All the members of assertive class can be assessed to include true or false, (Huang, 2007: 106; Cruse, 2002: 12).

2. directives: one of illocutionary acts in which the speaker informs the listener to do something. They may be very simple when someone invite you to do something, but they may be aggressive when someone insists you to do it, (Huang, p:107).

3. commissives: Cutting (2002: 17) classifies commissives as types of illocutionary acts to commit the speaker to some future course of action. It gives more elegant taxonomy if the speakers want to show that commissives and directives are members of the same category.

4. Expressives : are types of illocutionary acts which "are used to express the physical state specified by in the sincerity condition about a state of affairs specified in the propositional 
content", such as : joy, sorrow and like dislikes, (1979: 15).

5. Declaration : according to Sadock (2007: 9) states that the correspondences between the propositional content and reality is regarded as a performance of one of its members. He (ibid) adds that successful performance guarantees that propositional content corresponds to the world.

\subsection{Felicity conditions}

Felicitous speech acts are actions that gather with a suitable circumstance or "felicity conditions" of performative utterance. Pratt (1977, p: 81) explains that the speaker cannot perform a speech act by uttering a grammatical sentence only unless the speaker expresses the acts by certain conditions such as the act of promise. Promising someone means to do something to the hearer.

Searle (1969: 36) asserts that there are four types of felicity conditions in order to perform the actions according to specific rules. These conditions are:

\section{Propositional Content Condition:}

The performative utterance components that are found in the propositional content should be fulfilled the performed acts. This means that the speaker cannot express command by using the utterances of promise (Searle, 1980:321).

\section{Preparatory Conditions:}

This condition expresses that the speakers should have clear purposes when they try uttering utterances (Searle, 1980: 322- 323). For example, one cannot say that he is ordering someone when it is obvious that this person is already doing it or about to do this action.

\section{Sincerity Conditions:}

Searle (1980, p:323) and Harman (1971, p: $67)$ declare that with sincerity condition, the speaker and the hearer correctly tend to do the desired speech act. Moreover, Searle (1980, $\mathrm{p}: 323)$ insists that "the most important distinction between sincere and insincere promises is that the speaker intend to do the act of promise with sincere and does not with insincere".

\section{Essential Condition:}

The speakers and the hearers are committed to do the actions which are expressed by their utterances (ibid). In the line with this Malmkjaer (2005, p: 491) argues that essential condition of "promises" is that the speaker intends that his utterance will make him responsible for intending to do the promised act.

\section{SPEECH ACTS IN ARABIC}

From seventh century A. D. classical Arabic scholars realize that the study of syntax, semantics and pragmatics is related. Some books are written at that time such as "الكتاب" of (سيبويه ) (born 130 A.H). this book is considered as the beginning of linguistics to the book "مفتاح العلوم" of (السكاكي) ( born 625 A.H). these books offer systematic studies of the ways and styles people utilize in their spoken and written forms of language. Particular attention was given to speech structure and meaning ${ }^{(1)}$.

In contrast with Austin and Searle and their followers, the Arabs accommodated the theory of speech act within the general theory of rhetoric rather than pragmatics. They distinguished utterance meaning as either constative (Al-Khabar الخسو) or performative (Al-Inshaa (الانشاء). (See, الالوسي وصادق, 1961:99-101).

\subsection{Constative الخبر/}

Unlike utterance, meaning is considered as The first case is referred to as "الخبر" (constative), whereas the second as "الطلب اوالانشاء" (performative). An utterance of the former is often verified by being true or false (in respect of the speaker's judgement and the reality in the world).

(السكاكي ,مفتاح العلوم deals with the linguistic study as composed of three main components: (i) morphology, (ii) syntax, and (iii) meaning and rhetoric (or (البيان) which deals 


\subsection{Performative / الانثاء}

An utterancewhich is not likely to be true or false in itself is often referred to as : الانثاء. Such a type of utterance is of two broad groups: directive (الانشاء الطلبي) which requires the fulfilment of action not at hand at the time enunciating an utterance and Non-directive (الانثاء غير الطلبي)which does not require the fulfilment of an action.

\section{THE CONCEPT OF ADVICE}

Searle (1969, p: 52) who stated that giving advice is a kind of speech act which the speaker believeswill benefit the hearer. He further demonstrates that by giving advice, the speaker is doing the hearer a favour because it is not clear to both of them that the hearer will do the act without the advice being given.

Hinkel (1997, p:5) thinks that giving advice is a complex speech act that must be performed with caution when the speaker is reasonably certain that the hearer is likely to do what is being advised, that all sorts of advice must be softened and never given explicitly to avoid offending the hearer, and that the speaker is presupposed to have the right or the authority to give advice.

According to Brown and Levinson (1987, p:82), advice is to tell what is the best for someone. Advice belongs to the directive category of speech acts. As a directive act, the speaker wants his/her advisee to do something. In such case, giving advice is somehow related to a request with the difference that an advice is beneficial to its recipient. Advice is related to the group of advisories as part of speech act, which include suggestions and recommendations as well, it is considered to be of benefit to the hearer rather than the speaker and that it tells what is best for the hearer. The speaker might hope for a future act on the part of the hearer. In addition to that, speech act of advice is a potentially facethreatening act because it places the hearer into the position that she/he is asked to do something and thus limits the hearer's freedom of action, and because it puts the speaker into a position of authority and power, as someone knows what is good for the hearer, giving an advice leaves the advice getter with the responsibility to consider the advice seriously.

\section{DATA COLLECTION}

Data are collected randomly from different websites and some of the Arabic stories are selected from "Qais A. Hamad series". The stories are varied among comic, fairy, moral, grandparents' narrative stories, etc. they are divided between mother- son, father- son, fatherdaughter, animal- person, things- person. The number of the bedtime stories are 20 stories. They are English and Arabic stories.

While the analysis of the children's bedtime stories will focus on the use of advice in an eclectic modal and to show the most frequent type of advice and the most highly used of its strategies. The table is in to four columns and after it the explanation of the story according to felicity conditions.

\subsection{The Analysis}

\section{A. English stories}

1. Table (4) the analysis of the "Wise Thinking" story

\begin{tabular}{|c|l|l|l|}
\hline Structures & Types of advice & Strategies & Advisories \\
\hline a. "you must concentrate on the color \\
$\begin{array}{c}\text { green." } \\
\text { b. "Once you do that, the pain in your } \\
\text { eyes will disappeared" }\end{array}$ & Conventionally indirect & Declarative & Conditional \\
\hline c. "well" the servant replied politely \\
$\begin{array}{l}\text { "our master was advised by you to } \\
\text { look at green objects, in that manner } \\
\text { he would not feel any discomfort. As } \\
\text { you were wearing saffron - colored } \\
\text { garments. Our master would have } \\
\text { been uncomfortable" }\end{array}$ & Performative & Suggest \\
\hline
\end{tabular}


d. "All you could have done was buy a green shaded pair glasses, there was no reason to change everything."

\begin{tabular}{|l|l|l|}
\hline Conventionally indirect & Declarative & Suggest \\
\hline
\end{tabular}

\section{1- Felicity condition of advice in the "Wise Thinking" story}

1. The Propositional Content Condition (PCC): by advising the man to see green things only, the monk wishes the man to do the act.

2. The Preparatory Condition: it seems that the speaker (the monk) has some reason to believe that the act (to see the green things) will benefit the hearer (the king ).

3. The Sincerity Condition: the monk believes that his advice will be benefit for the rich man because the green color is used to comfort his pain.

4. The essential condition: the monk intend his utterance to count as an advice to the rich man.

2. Table (5), the analysis of the "The ant and the grasshopper" story

\begin{tabular}{|c|l|l|l|}
\hline Structure & Types of advice & Strategies & Advisories \\
\hline a. Don't ever get tired of playing?" & Conventionally indirect & Interrogative & Admonish \\
\hline b. "Don't you ever work?" & Conventionally indirect & Interrogative & Admonish \\
\hline $\begin{array}{l}\text { c. "because the winter will be here soon, } \\
\text { and food will be too hard to find and } \\
\text { you should do the same" }\end{array}$ & Direct & Declarative & Recommend \\
\hline
\end{tabular}

\section{2- Felicity condition of advice in the "The Ant and The Grasshopper" story}

1. The propositional content condition (PCC): with the ant's advice by storing the food for winter season, the grasshopper should follow this advice and get rid of playing and singing all the time.

2. The preparatory condition: it is not obvious to the ant that the grasshopper will take her advice concerning store the food for winter.

3. The sincerity condition: the ant believes that her advice will be benefit the grasshopper in that it will help him to stop losing his time in unfruitful work.

4. The essential condition: the ant intends her utterance to count as an advice to the grasshopper.

\section{B. Arabic stories}

1- Table (14), the analysis of the "Najwa and The Three Bowls" story

\begin{tabular}{|c|l|l|l|}
\hline Structures & Types of advice & Strategies & Advisories \\
\hline $\begin{array}{l}\text { a. "why don't you let me come up } \\
\text { from the wetted sand to carry your } \\
\text { summer milk and winter soup?" }\end{array}$ & Conventionally indirect & Interrogative & Admonish \\
\hline $\begin{array}{l}\text { b. } \\
\text { out... I'll have a bless of heaven } \\
\text { whenever and wherever I exist" }\end{array}$ & & Imperative & Advise \\
\hline $\begin{array}{l}\text { "when you wash me, I'll shine like the } \\
\text { moon." }\end{array}$ & Conventionally indirect & Conditional & Urge \\
\hline d. "Stretch your hand out" & Direct & Imperative & Advise \\
\hline e. She tried to throw it back to the river & Conventionally indirect & Conditional & Urge \\
\hline
\end{tabular}


because she hoped to gain the gold bowel. But she heard it saying with insistence: "I am tired of being buried under the mercy of sand and water, you'll see the generous bestow of blessing given by God. If He wishes you'll see."

\section{1- The felicity condition of " Najwa and the three bowls" story}

1. The prepositional content condition(PCC): each one of the three bowels advices Najwa to take it for some advantages of them.

2. The preparatory condition: it is obvious that Najwa will take the advice from bowels and choose one of them.

3. The sincerity condition: the bowels believes that their advice will benefit Najwa.

4. The essential condition: the bowels intends that their utterance to count as an advice.

2. Table (15), the analysis of the "The red flower" story

\begin{tabular}{|c|c|c|c|}
\hline Structure & Types of advice & Strategies & Advisories \\
\hline $\begin{array}{l}\text { a. During his quick departure, he heard a } \\
\text { flower said to him as she struggled to } \\
\text { death: "Do not be sad "Abdulla" } \\
\text { please" }\end{array}$ & Direct & Neg. Imperative & Advise \\
\hline b. "carry me out with my branch" & Direct & Imperative & Suggest \\
\hline $\begin{array}{l}\text { c. The flower answered: "start to build } \\
\text { a new house up the hills- the land } \\
\text { there is so fertile." }\end{array}$ & Direct & Imperative & Advise \\
\hline $\begin{array}{l}\text { d. "carry me and plant me in your new } \\
\text { garden with other fruitful trees." }\end{array}$ & Direct & Imperative & Suggest \\
\hline
\end{tabular}

2- the felicity condition of "The red flower" story

1. The prepositional content condition (PCC): the flower advices Abdullah to take it with him and to follow its instruction

2. The preparatory condition: it is obvious that Abdullah will take the benefit from the advice which is given by the flower.

3. The sincerity condition: the flower believes that its advice will benefit Abdullah.

4. The essential condition: the flower intends that Abdullah will take its utterance as an advice.

\section{DISCUSSION AND CONCLUSION}

The present study has focused on speech act of advice in the English and Arabic bedtime stories. This study is proved to number of models about types of advice, strategies and advisories. All these models are collected in one adopted model. the directive speech act is used with its types in both Arabic and English stories and that was axis of the study. This can be concluded from the theory 'University of language' by Chomsky that speech act theory can be applied with all languages. The speech act of advice comprehends explicitly and implicitly in English and Arabic stories. Traditions have a logical meaning, i.e. either encouraging the hearer to take an action that is advantageous to him / her or stopping him / her from doing it when it has bad consequence. 
Directive speech act is a special form of speech act because the hearer must carry out the task, and it is a characteristic that separates Directive speech act from other types of speech act. While advice is the most common type of directives which means that the speaker directs the hearers to do a good action.Advice implies a future action that is only beneficial to the listener. The direct strategy scores the highest percentage in the form of imperative while the indirect conventionalized is rarely used in English bedtime stories and this refutes the hypothesis which indicates that indirect conventionalized is the most frequented one. with the Arabic bedtime stories, the results come in agreement with the hypothesis that indirect conventionalized scores the highest percentage.

\section{BIBLIOGRAPHY}

1. Austin, J. L. (1962). How to do things with words. Oxford: The Clarendon Press.

2. Bach, K. (1999). Speech act and pragmatics. USA:New York.

3. Bach, K. and Harnish, R. M. (1979). Linguistic communication and speech acts. Cambridge: The MIT Press.

4. Crystal, D. (2008). A dictionary of linguistics and phonetics. Oxford: Blackwell Press.

5. Curse, A. (2002). Meaning in Language: An Introduction to semantics and Pragmatics. New York: Oxford University Press.

6. Cutting, J. (2002). Pragmatics and Discourse: A Source Book for Student. USA: Library of Congress.

7. Finch, G. (2000). Linguistic terms and concepts. London: Macmillan press Ltd.

8. Haiman, Franklyn S. (1993). Speech acts. And the first Amendment. USA: Southern Illinois University Press.

9. Harman, E.G. (1971). Three Levels of Meaning: An Interdisciplinary Reader in Philosophy, Linguistics and Psychology. London: Cambridge University Press.

10. Huang, Y(2007). Pragmatics. Oxford: Oxford University Press.

11. Levinson, S. (1983). Pragmatics. Cambridge: Cambridge University Press.

12. Malmkjaer, K. (2005). The Linguistics Encyclopedia. New York: Taylor and Francis e- library.

13. Mey, J. L. (2001). Pragmatics: An Introduction. $2^{\text {nd }}$ edn. Oxford: Blackwell

14. Mey, L. (1993). Pragmatics. Oxford: Blackwell Publishers.

15. Moffett, J. (1968). Teaching the universe of discourse. Boston: HoughtonMifflin.

16. Morris, C.(1938). The foundation of the theory of signs. Chicago: Chicago University Press.

17. Pratt, M. L. (1977). Toward a speech act theory of literary discourse. Bloomington: Indian University Press.

18. Sadock. J.M. (1974). Toward a linguistic Theory of speech acts. New York: Academic Press.

19. Searle, J. R. (1969). Speech Acts: An essay in the philosophy of language. Cambridge: Cambridge University Press.

20. Searle, J. R. (1971) "What is a Speech Act". The Philosophyof Language. London . oxford University press.

21. Searle, J. R. (1979). Expression and Meaning. Cambridge. Cambridge University Press.

22. Yule, G. (1996). Pragmatics. Oxford: Oxford University Press.

\section{Arabic Bibliography}

$$
\begin{aligned}
& \text { 23. الآلوسي ، جمال الدين و عبد الرضاصادق (1961) البلاغة. بغداد : مطبعة الارشاد. } \\
& \text { 24. السكاكي، يوسف ابي بكر محم (1980) مفتاح العلوم، تحقيق اكرم عثمان. بغداد: دار الرسالة. }
\end{aligned}
$$

